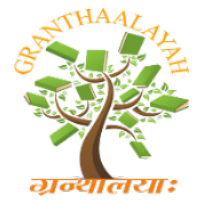

\author{
INTERNATIONAL JOURNAL OF RESEARCH - \\ GRANTHAALAYAH \\ A knowledge Repository
}

Science

\title{
EFFECT OF FEEDING DIFFERENT INCLUSION RATES OF WATER HYACINTH [EICHHORNIA CRASSIPES (MART.) SOLMS] ON THE BODY WEIGHT GAIN OF GROWING DAIRY BULL CALVES
}

\author{
Nieta C. Amit ${ }^{* 1}$, A. R. Esaga ${ }^{1}$, M.G. E. Villanueva ${ }^{1}$, G. L. Manulat ${ }^{2}$, E.E.C. Abes ${ }^{2}$, T. J. \\ Bacorro $^{2}$, I. G. Sarmago ${ }^{2}$, A.J. Salces ${ }^{3}$, B. C. Cruzana ${ }^{4}$, A.A. Rayos ${ }^{2}$ \& A. A. Angeles ${ }^{2}$ \\ ${ }^{1}$ Institute of Animal Science, College of Agriculture and Food Science, University of the \\ Philippines Los Baños, College, Laguna \\ 2 Dairy Training and Research Institute, College of Agriculture and Food Science, University of \\ the Philippines Los Baños, College, Laguna \\ ${ }^{3}$ Animal Breeding Division, Institute of Animal Science, College of Agriculture and Food \\ Science, University of the Philippines Los Baños, College, Laguna \\ ${ }^{4}$ College of Veterinary Medicine, University of the Philippines, Los Baños, College, Laguna
}

ORCID ID: http://orcid.org/0000-0001-8392-0950

\begin{abstract}
Twenty-four (24) Holstein Friesian-Sahiwal crossbred growing dairy bull calves with average weight of $87.30 \mathrm{~kg}$ were used to evaluate the effect of feeding water hyacinth (WH) on the Body Weight Gain (BWG) of growing dairy bull calves at the Dairy Training and Research Institute (DTRI), Dairy Farm, College of Agriculture and Food Science, University of the Philippines (UPLB), College, Laguna from August 2017 to December 2017. WH at 0, 10, 20 and 40\% dry matter (DM) basis substitution of Napier grass in the total mixed ration (TMR) served as treatments in six (6) randomized complete blocks, each block consisting of calves at the same weight range. WH at $40 \%$ caused increased DM intake in calves but feeding WH to calves did not affect body weight (BW) gain of the calves. Therefore, WH can be used as an alternative feed source at an inclusion rate of $10-20 \%$ dry matter basis substitution of Napier grass.
\end{abstract}

Keywords: Inclusion; Body Weight Gain; Water Hyacinth.

Cite This Article: Nieta C. Amit. (2019). "EFFECT OF FEEDING DIFFERENT INCLUSION RATES OF WATER HYACINTH [EICHHORNIA CRASSIPES (MART.) SOLMS] ON THE BODY WEIGHT GAIN OF GROWING DAIRY BULL CALVES." International Journal of Research - Granthaalayah, 7(5), 293-298. https://doi.org/10.5281/zenodo.3241277. 


\section{Introduction}

Cattle is one of the most common animals raised in rural areas. These mammals are of great importance to humans because aside from producing meat and milk, they can also be used as draft animals in small farmlands. Some people grow cattle because of tradition, while some as a source of extra income. However, the ruminant industry is challenged by the decreasing pasture area and the availability of forage during the dry season. Thus, water hyacinth $(\mathrm{WH})$ is considered as an alternative feed source for ruminants due to increasing prices of feeds.

Water hyacinth (WH) is considered as an invasive and a nuisance aquatic plant. Considering WH as an alternative feed source for ruminants is vital and timely since the ruminant industry is being challenged by the decreasing pasture areas due to land use conversion and that feeds are becoming more expensive. Alternative feed sources are important during dry season when forage for ruminants are scarce. Availability of forage limits production performance. The high protein content in the leaves of WH (19.5\%) makes it a potential fodder source for cows, goats, pigs, ducks and tilapia fingerlings in other countries (Sophal et al., 2010). In Thailand, fresh WH is recommended at an inclusion level of not more than $30 \%$ of diet dry matter (Tham, 2015). In Northern Samar, Philippines, farmers are already using water hyacinth as feed for cattle, carabaos and pigs. They chop the whole plant, cook and add sweet potato leaves, hogwash and salt. The mixed ration is locally known as "loon".

The study aimed to determine the body weight gain (BWG), of growing dairy bull calves fed different inclusion rates of WH.

\section{Materials and Methods}

\section{Ethical Approval}

The experiment was conducted in accordance with the protocol set by the Institutional Animal Care and Use Committee (IACUC) of the University of the Philippines Los Baños (UPLB), College, Laguna.

\section{Site and Duration of the Study}

The experiment was carried out at the Dairy Training and Research Institute (DTRI) Dairy Farm, College of Agriculture and Food Science, UPLB, College, Laguna from August 2017 to December 2017.

\section{Experimental Design}

Twenty-four apparently healthy growing dairy bull calves (Holstein Friesian-Sahiwal crossbreeds) approximately four (4) months of age with an average weight of $87.30 \mathrm{~kg}$ were divided into four groups and assigned to one of the four treatments in a randomized complete block design (RCBD) with the weight of calves as the blocking factor. Each treatment was composed of six (6) calves with each replicate calf housed in individual stalls. The treatments were composed of the TMR with $0,10,20$, and $40 \%$ substitution of Napier grass by WH on dry matter basis.

\section{Experimental Animals and their Management}

Twenty-four apparently healthy growing dairy bull calves, approximately four (4) months of age with average weight of $87.30 \mathrm{~kg}$ were used as experimental animals. Each calf was housed in 
individual stalls using nylon rope inserted in plastic hose tied around their neck. The length of the rope is enough for the animals to move comfortably. The health status of the calves such as external and internal parasites, respiratory problems, calf scours and other health problems that occurred was monitored during the experimental period. The physiological values were also checked. The animals were quarantined for one month before the start of the experiment.

\section{Feeding Management}

WH was fed as a part of the total mixed ration (TMR) composed of Napier grass, silage, concentrate, molasses and salt. Chopped fresh aerial part of WH with inclusion rates of 10, 20 and $40 \%$ substitution rate of DM from Napier grass was incorporated in the TMR for the whole duration of the experiment.

Silage was either corn, sorghum or mombasa (Panicum maximum) grass added with molasses while the concentrate was a mixture of yellow corn, copra meal expeller, soybean meal, vegetable oil, molasses, salt, limestone, mineral premix, antioxidant and mold inhibitor. Fresh, clean water and ad libitum feeding were offered in the morning and provided throughout the duration of the experiment. The chemical composition of WH and Napier grass used in this study is presented in Table 1 while the formulation and calculated composition of the diet and chemical composition of the Total Mixed Ration (TMR) fed to the experimental calves are presented in Tables 2 and 3.

\section{Evaluation of Body Weight Gain (BWG)}

Feed intake of the control and treated calves were recorded daily by subtracting the feed refusal from the feed offered, on a dry matter basis. Body weight was measured by using a platform weighing scale. Liveweight was determined by weighing the calves every two (2) weeks during the experimental period using an electronic platform weighing scale. The BWG was computed using the formula of Sreedar (2015) by deducting the final weight from the initial weight.Statistical Analysis

Data gathered were analyzed using the MIXED procedure of SAS (SAS Institute, 2014). The model considered treatments as fixed effects and blocks as random effects. Least significant means were used to compare treatment means. Statistical significance and tendencies were set at $P$ value $\leq 0.05$.

\section{Results and Discussion}

\section{Body Weight}

Table 1 shows the body weights of growing dairy bull calves at different observation periods. Body weights of calves increased from Week 0 to Week 14 across treatments except at Week 2 at $10 \%$ inclusion rate of $\mathrm{WH}$ where a slight decrease was observed. The decrease in weight was probably due to some health problems that occurred on week 2 such as diarrhea and respiratory problem.

However, body weights were not affected by treatments, suggesting that increasing inclusion levels of WH into the TMR did not affect body weight. Moreover, the 7-9 kg numerical difference in body weight between the control and the treatments could be significant to the cattle raiser. WH can be used as a supplemental forage to animals especially when feed supply becomes scarce. 
Apparently, the inclusion of WH at increasing rates after a 90-day trial demonstrate that it did not affect body weight of calves. This can be attributed to the high fiber content of WH which is $56.67 \%$ neutral detergent fiber (NDF) and 78.67\% acid detergent fiber (ADF). It also suggests that $\mathrm{WH}$ as an additive or substitute to basal ration can be fed to animals to help solve dry seasonal feed shortage.

Results of the present study do not conform to the study conducted by Akovbovbo et al. (2012) on the performance evaluation of weaner pigs fed graded levels of WH. There was a mild insignificant progressive reduction of weight with increasing levels of $\mathrm{WH}$ in the ration to compensate for reduction in the energy intake. The study used 10, 20 and 30\% inclusion of WH for a period of 70 days. The basal diet was composed of soy bean meal. All the diets were supplemented with vitamins and mineral premixes.

Findings are supported with the study of Tham (2012) that WH can be fed in levels of at least 50\% of diet dry matter to growing cattle and that inclusion level of fresh WH should not exceed $30 \%$. He stressed the need for a long adaptation period to fresh WH feeding. Hadgu (2016) stated that the limiting factor to forage intake would be the ruminal fill provided by the fiber. Hence, this significant effect could be attributed to increasing inclusion levels of WH and its interaction with the ruminal filling of experimental animals across observation periods.

Table 1: Body weight (kg) of growing dairy bull calves fed TMR with increasing inclusion rates of WH calculated every two weeks.

\begin{tabular}{|l|l|l|l|l|l|l|}
\hline \multirow{2}{*}{ PARAMETER } & \multicolumn{3}{|l|}{ TREATMENTS } & \multirow{2}{*}{ MSE } & \multirow{2}{*}{ P-value } \\
\cline { 2 - 6 } & $\begin{array}{l}\mathbf{0 \%} \\
\mathbf{W H}^{\mathbf{1}}\end{array}$ & $\begin{array}{l}\mathbf{1 0 \%} \\
\mathbf{W H}^{\mathbf{2}}\end{array}$ & $\mathbf{2 0 \%} \mathbf{W H}^{\mathbf{3}}$ & $\mathbf{4 0 \%} \mathbf{W H}^{\mathbf{4}}$ & & \\
\hline Week 0 & 87.33 & 87.00 & 87.42 & 87.42 & 6.94 & 0.9968 \\
\hline Week 2 & 88.50 & 86.42 & 89.08 & 91.92 & 6.97 & 0.1525 \\
\hline Week 4 & 92.67 & 93.33 & 93.25 & 95.67 & 7.97 & 0.8717 \\
\hline Week 6 & 101.92 & 100.83 & 102.00 & 100.17 & 8.35 & 0.7603 \\
\hline Week 8 & 107.17 & 107.50 & 108.50 & 107.58 & 8.84 & 0.9882 \\
\hline Week 10 & 114.87 & 108.15 & 111.77 & 113.85 & 9.19 & 0.5988 \\
\hline Week 12 & 124.38 & 117.60 & 120.13 & 123.22 & 10.26 & 0.7187 \\
\hline Week 14 & 135.57 & 127.92 & 128.23 & 126.72 & 10.80 & 0.4303 \\
\hline
\end{tabular}

Legend: ${ }^{1} 0 \% \mathrm{WH}$ - Napier grass as basal diet; ${ }^{2} 10 \% \mathrm{WH}-10 \% \mathrm{WH}$ in the diet; ${ }^{3} 20 \% \mathrm{WH}-20 \% \mathrm{WH}$ in the diet; ${ }^{4} 40 \% \mathrm{WH}-40 \% \mathrm{WH}$ in the diet

\section{Body Weight Gain}

Table 2 shows no significant differences on body weight gain of growing dairy bull calves fed TMR with increasing inclusion rates of WH calculated every two weeks. The present study reveal that increasing the inclusion levels of WH into the TMR did not increase body weight gain which could be due to the fiber content in fresh WH. Results of the feeding trial in the present study at inclusion rates of $0,10,20$ and $40 \% \mathrm{WH}$ are relatively consistent with the findings of Sulieman and Lado (2011) in Nile tilapia fingerlings wherein they observed that the feed with the lower amount of WH had better growth performance. Moreover, they found that increasing level of WH in the feed meal produced significantly poorer weight gain than WH-free diets after the 50-day feeding trial. 
In the study of Sophal et al. (2010) on the effects of supplements of water hyacinth and cassava hay on the performance of local "Yellow" cattle fed a basal diet of rice straw, they reported a significant interaction between the effect of the cassava hay and the rumen supplements. Growth rates were higher when the leaves of water hyacinth plus cassava hay were given as the rumen supplement with no difference between water hyacinth leaves plus stem and the urea-mineral mixture. In the absence of cassava hay, the cattle fed either leaves or leaves plus stem of water hyacinth lost body weight while those fed the urea-mineral mixture gained in weight. Furthermore, Sophal et al. (2010) reported that when fresh leaves of WH plus cereals and cassava hay were fed to cattle, an ADG of $243 \mathrm{~g} /$ day was observed. When cattle were fed in the same study with fresh leaves and stems of WH plus cereals and cassava hay, the ADG was 147g/day. WH can be used effectively as source of rumen nutrients for growing cattle on a basal diet of rice straw provided that a source of bypass protein such as cassava hay be incorporated in the ration.

Hira et al. (2002) used WH leaves as a replacement for Dhal grass in the diet of goat with an inclusion rate of 25, 50 and $100 \%$ for 60 days. All the goats were provided with 200 grams of concentrate and feeds were given twice a day. It was observed that $25 \% \mathrm{WH}$ plus $75 \%$ Dhal grass showed an increase in body weight while the $100 \% \mathrm{WH}$ showed poor performance. In the present study, all the experimental calves gained weight except in the $10 \% \mathrm{WH}$ inclusion at week 2 with a negative weight gain and could possibly be due to the health problems that occurred to three (3) calves in $10 \% \mathrm{WH}$ which had nasal discharge, diarrhea and cough which lasted for two (2) days.

Table 2: Cumulative body weight gain $(\mathrm{kg})$ of growing dairy bull calves fed TMR with increasing inclusion rates of WH calculated every two weeks.

\begin{tabular}{|c|c|c|c|c|c|c|}
\hline \multirow{2}{*}{ PARAMETER } & \multicolumn{4}{|c|}{ TREATMENTS } & \multirow[t]{2}{*}{ MSE } & \multirow[t]{2}{*}{$P$-value } \\
\hline & $\begin{array}{l}\mathbf{0 \%} \\
\mathrm{WH}^{1}\end{array}$ & $\begin{array}{l}10 \% \\
\mathrm{WH}^{2}\end{array}$ & $20 \% \mathrm{WH}^{3}$ & $40 \% \mathrm{WH}^{4}$ & & \\
\hline Week 2 & 1.83 & -0.58 & 1.67 & 4.50 & 1.28 & 0.0578 \\
\hline Week 4 & 6.00 & 6.33 & 5.83 & 8.25 & 1.94 & 0.7982 \\
\hline Week 6 & 15.25 & 13.83 & 14.58 & 12.75 & 1.95 & 0.7349 \\
\hline Week 8 & 18.00 & 20.50 & 21.08 & 20.17 & 2.83 & 0.7770 \\
\hline Week 10 & 25.70 & 21.15 & 24.35 & 26.43 & 3.58 & 0.6037 \\
\hline Week 12 & 37.05 & 30.60 & 32.72 & 35.80 & 4.16 & 0.5602 \\
\hline Week 14 & 48.23 & 40.91 & 40.81 & 39.30 & 4.55 & 0.2159 \\
\hline
\end{tabular}

Legend: ${ }^{1} 0 \% \mathrm{WH}$ - Napier grass as basal diet; ${ }^{2} 10 \% \mathrm{WH}-10 \% \mathrm{WH}$ in the diet; ${ }^{3} 20 \% \mathrm{WH}-20 \% \mathrm{WH}$ in the diet; ${ }^{4} 40 \% \mathrm{WH}-40 \% \mathrm{WH}$ in the diet

\section{Conclusion}

Water Hyacinth can be used as an alternative feed source for growing dairy bull calves at 10-20\% inclusion rate to ensure its optimal utilization. Several studies reported that an inclusion level of fresh WH should not exceed $30 \%$ to avoid problems of bloat and a long adaptation period to fresh WH should be done. WH at 40\% inclusion rates caused increased DM intake in calves but did not affect body weight gain. 


\section{Acknowledgement}

This work was supported by the Department of Agriculture-Bureau of Agricultural Research (DABAR) and the Dairy Training and Research Institute (DTRI) Dairy Farm, College of Agriculture and Food Science, University of the Philippines Los Banos, Laguna.

\section{References}

[1] Akpovbovbo, G., P.K. Ajuogu, J. N. Akankali, O.S. George, \& M.A. Yahaya. 2012. Performance Evaluations of Weaner Pigs Fed Graded Levels of Water Hyacinth (Eicchornia crassipes). Waste Management and Bioresource Technology (2) 8-13.

[2] Hadgu, G.Z. 2016. Factors Affecting Feed Intake and Its Regulation Mechanisms in Ruminants A Review. Internati Hira, A. K., Ali, M. Y., Chakraborty, M., Islam, M. A. And M. R. Zaman. 2002. Use of water-hyacinth leaves (Eichhornia crassipes) replacing dhal grass (Hymenachne pseudointerrupta) in the diet of goat. Pakistan J. Biol. Sci., 5: 218-220.

[3] onal Journal of Livestock Research, 6 (4), 19- 40

[4] SAS Institute Inc. 2014. SAS ${ }^{2}$ University Edition User's Guide. SAS Institute Inc., Cary, NC.

[5] Sophal, C., K. Borin, \& T.R. Preston. 2010. Effects of supplements of water hyacinth and cassava hay on the performance of local "Yellow" cattle fed a basal diet of rice straw. Livestock Research for Rural Development, 22 (166).

[6] Sreedar, S. 2015. Growth Performance of Indigenous and Cross Bred Calves in Coastal Region of Andhra Pradesh. Livestock Research International, 3 (4): 99-102.

[7] Suleiman, H.M., \& E.F. Lado. 2011. Nutritional effectiveness of water hyacinth leaves combined with wheat bran and cotton seed cake on the performance of Nile tilapia (Orechromis niloticus). Online J Anim Feed Res. 1:306-309.

[8] Tham, H.T. 2012. Water Hyacinth (Eichhornia crassipes) Biomass Production, Ensilability and Feeding Value to Growing Cattle. PhD Thesis. Swedish University of Agricultural Sciences.

\footnotetext{
*Corresponding author.

E-mail address: NCAmit@yahoo.com
} 